\title{
PERANAN KREDIT USAHA RAKYAT (KUR) DALAM MENGEMBANGKAN INDUSTRI KECIL MENENGAH (IKM) KOTA TEGAL
}

\author{
Ida Farida \\ Politeknik Harapan Bersama Tegal \\ idafaridah90@yahoo.com \\ Aryanto \\ Politeknik Harapan Bersama Tegal \\ Ary.arya70@gmail.com \\ Sunandar \\ Politeknik Harapan Bersama Tegal \\ Nandars2ak@gmail.com
}

\begin{abstract}
Small and medium industries (IKM) play an important role in economic development because the employment rate is relatively high and the capital investment needs are small. Currently improving the performance of small and medium industries (IKM) is still being hit by various obstacles and challenges in the face of competition. Barriers and challenges faced by SME entrepreneurs in improving their business performance are limited capital. The role of banks in economic development is to channel funds for economic activities, one of which is in the form of credit for individual or business entities. Bank Rakyat Indonesia (BRI) has a commitment to help develop Small and Medium Industries (IKM) and improve community welfare.

This study aims to determine the role of Business Credit (KUR) in developing Small and Medium Industries (IKM) in Tegal City. This type of research is causative research with survey methods to explain the role of the People's Business Credit (KUR) for the development of Small and Medium Industries.
\end{abstract}

Keywords:People's Business Credit (KUR), Small and Medium Industries (IKM)

\section{PENDAHULUAN}

Industri kecil dan menengah (IKM) memegang peran penting dalam pembangunan ekonomi karena tingkat penyerapan tenaga kerja relatif tinggi dan kebutuhan modal investasinya kecil. Rendahnya tingkat investasi dan produktivitas, serta rendahnya pertumbuhan usaha baru di Indonesia perlu memperoleh perhatian yang serius pada masa yang akan datang dalam rangka mengembangkan Industri kecil dan menengah (IKM) menuju usaha yang berdaya saing tinggi.

Saat ini peningkatan kinerja Industri kecil dan menengah(IKM) masih dilanda berbagai hambatan dan tantangan dalam 
menghadapi persaingan.Hambatan dan tantangan yang dihadapi oleh pengusaha IKM dalam meningkatkan kinerja usahanya adalah keterbatasan modal yang dimiliki.Permodalan merupakan salah satu masalah mendasar yang dihadapi oleh IKM dengan terbatasnya akses mereka terhadap sumber-sumber pembiayaan dari lembaga keuangan perbankan, menurut Wijino (2005) dalam Maratis (2014). Keterbatasan modal tersebut akan mempengaruhi kinerja IKM yaitu menurunnya kemampuan dalam memproduksi barang dan jasa secara efektif, berkurangnya jumlah tenaga kerja yang mengakibatkan ruang lingkup usaha menjadi terbatas, pendapatan usaha menjadi rendah karena tidak ada barang yang dijual, dan efisiensi produksi yang tidak berjalan dengan baik sehingga biaya produksi menjadi tinggi. Bagi pengusaha IKM, kredit dirasa cukup penting mengingat kebutuhan pembiayaan modal kerja dan investasi diperlukan untuk menjalankan usaha dan meningkatkan kinerja usahanya.

Peran perbankan dalam pembangunan ekonomi adalah mengalirkan dana bagi kegiatan ekonomi yaitu salah satunya dalam bentuk perkreditan bagi masyarakat perseorangan atau badan usaha. Bank Rakyat Indonesia (BRI) memiliki komitmen untuk membantu mengembangkan Industri Kecil
Menengah (IKM) serta meningkatkan kesejahteraan masyarakat. Salah satu bentuk komitment itu adalah dengan dibukanya kredit untuk modal usaha bagi IKM dan koperasi yang disebut dengan Kredit Usaha Rakyat ( KUR ). KUR ini merupakan alternatif bagi Usaha Kecil, Mikro dan Koperasi untuk mendapatkan modal usaha. Karena itulah Bank BRI Cabang Tegal melalui Kredit Usaha Rakyat ini bermaksud memberikan kemudahan akses yang lebih besar bagi para pelaku usaha mikro, kecil, menengah dan koperasi, yang sudah feasible tetapi belum bankable mendapatkan modal usaha. Pinjaman modal usaha ini merupakan alternatif yang cocok bagi pelaku IKM.

KUR diberikan oleh BRI Cabang Tegal kepada para pengusaha industri kecil menengah di Kota Tegal yang mengalami kekurangan modal dalam pengembangan usahanya.Modal merupakan aspek paling berpengaruh dalam mendirikan suatu usaha.Jika modal yang digunakan tidak sebanding dengan jumlah produksi yang dilakukan, maka produsen harus mengurangi jumlah produksinya sesuai dengan modal yang di punya.Dengan keterbatasan modal yang dialami oleh sebagian besar pengusaha Industri Kecil Menengah.Bertitik tolak dari latar belakang masalah di atas, maka perumusan masalah ini adalah: "Bagaimana 
Peranan Program Kredit Usaha Rakyat (KUR) dalam Mengembangkan Industri Kecil Menengah (IKM) di Kota Tegal?".Tujuan dari penelitian ini adalah untuk mengetahui peranan Program Kredit Usaha Rakyat (KUR) dalam mengembangkan Industri Kecil Menengah (IKM) di Kota Tegal.

\section{TINJAUAN PUSTAKA \\ PENGEMBANGAN HIPOTESIS}

DAN

\subsection{Tinjauan Atas Kredit}

\subsubsection{Pengertian Kredit}

Menurut

Sastradipoera

(2004:151) kredit adalah penyedian uang atau tagihan (yang disamakan dengan uang) berdasarkan kesepakatan pinjam meminjam antara bank dan pihak lain yang dalam hal ini peminjam berkewajiban melunasi kewaibannya setelah jangka waktu tertentu dengan (biasanya) sejumlah bunga yang ditetapkan leih dahulu.

\subsubsection{Unsur-unsur Kredit}

Adapun unsur-unsur yang terkandung tersebut dalam pemberian kredit adalah (Abdulkadir dan Rilda, 2000: 59) :

\section{Kepercayaan}

Berdasarkan analisis yang dilakukan terhadap permohonan kredit yang akan diberikan itu dapat dikembalikan sesuai dengan persyaratan yang disepakati bersama.

2. Agunan

Setiap kredit yang akan diberikan selalu disertai barang yang berfungsi sebagai jaminan bahwa kredit yang akan diterima oleh calon debitur pasti akan dilunasi dan ini meningkatkan kepercayaan pihak bank.

3. Jangka Waktu

Pengembalian kredit didasarkan pada jangka waktu tertentu yang layak, setelah jangka waktu berakhir kredit dilunasi.

4. Risiko

Jangka waktu pengembalian kredit mengandung risiko terhalang, atau terlambat, atau macetnya pelunasan kredit, baik di sengaja atau tidak sengaja, risiko ini menjadi beban bank.

\section{Bunga Bank}

Setiap pemberian kredit selalu disertai imbalan jasa berupa bunga yang wajib dibayar oleh calon debitur, dan ini merupakan keuntungan yang diterima oleh bank.

6. Kesepakatan 
Semua persyaratan pemberian kredit dan prosedur pengembalian kredit serta akibat hukumnya adalah hasil kesepakatan dan dituangkan dalam akta perjanjian yang disebut kontrak kredit.

\subsubsection{Prinsip Pemberian Kredit}

Menurut Abdulkadir dan Rilda (2000: 61) Apabila Bank menerima permohonan kredit dari nasabah, bank perlu melakukan analisis kredit terlebih dahulu. Analisis kredit meliputi:

a. Latar belakang nasabah/ perusahaan nasabah;

b. Prospek usaha yang akan dibiayai;

c. Jaminan yang diberikan

d. Hal-hal lain yang ditentukan oleh bank.

Atas dasar hasil analisis kredit, bank memberikan pertimbangan dengan hati-hati apakah permohonan nasabah tersebut layak untuk dikabulkan. Adapun prinsip-prinsip pemberian kredit konsep 5C ( Dahlan Siamat, 1995) :
a. Character (Watak)
b. Capacity (Kemampuan)
c. Capital (Modal)
d. Collateral (Jaminan)
e. Condition (Keadaan)

Selain penilaian berdasarkan konsep 5C, terdapat juga penilaian kredit terhadap beberapa aspek yang menyangkut kegiatan usaha calon debitur yaitu :
a. Aspek Pemasaran
b. Aspek Teknis
c. Aspek Manajemen
d. Aspek Yuridis
e. Aspek Sosial Ekonomi

\subsection{Tinjauan Atas Kredit Usaha Rakyat (KUR)}

\subsubsection{Pengertian Kredit Usaha Rakyat (KUR)}

Kredit Usaha Rakyat, yang selanjutnya disingkat KUR, adalah kredit/pembiayaan kepada Usaha Mikro Kecil Menengah Koperasi (UMKM-K) dalam bentuk pemberian modal kerja dan investasi yang didukung fasilitas penjaminan untuk usaha produktif. KUR adalah program yang dicanangkan oleh pemerintah namun sumber dananya berasal sepenuhnya dari dana bank. Pemerintah memberikan penjaminan terhadap resiko KUR sebesar $70 \%$ sementara sisanya sebesar $30 \%$ ditanggung oleh bank pelaksana. Penjaminan KUR diberikan dalam rangka meningkatkan akses UMK pada sumber pembiayaan dalam rangka mendorong pertumbuhan ekonomi nasional ( BI , 2010 ).

Bank Rakyat Indonesia Unit ( BRI Unit ) merupakan salah satu dari unit kerja 
Bank Rakyat Indonesia ( BRI ) yang melayani kegiatan usaha perbankan pada segmen mikro. Secara struktural BRI Unit berada di level paling bawah dalam struktur organisasi BRI.Unit kerja yang berada di atas BRI Unit secara berturut-turut adalah Kantor Cabang, Kantor Wilayah dan Kantor Pusat.Formasi standar pekerja di BRI Unit cukup sederhana, yaitu terdiri dari empat fungsi.Fungsi-fungsi tersebut adalah Kepala Unit, Mantri, Teller dan Deskman yang harus ditangani minimal oleh empat orang pekerja, yang merupakan jumlah standar pekerja di BRI Unit.

KUR yang disalurkan melalui BRI sebagai salah satu bank pelaksana yang merupakan fasilitas kredit atau pembiayaan yang khusus diperuntukan bagi kegiatan usaha mikro, kecil dan menengah serta koperasi yang usahanya cukup layak namun tidak mempunyai agunan yang cukup sesuai dengan persyaratan yang telah ditetapkan oleh pihak perbankan.Program KUR bertujuan untuk meningkatkan perekonomian khususnya di bidang usaha mikro, kecil dan menengah, pengentasan kemiskinan dan penyerapan tenaga kerja.

\subsubsection{Ketentuan Kredit Usaha Rakyat} (KUR)

Penyaluran KUR diatur oleh pemerintah melalui Peraturan Menteri
Keuangan No. 135/PMK.05/2008 tentang Fasilitas Penjaminan Kredit Usaha Rakyat yang telah diubah dengan Peraturan Menteri Keuangan No. 10/PMK.05/2009. Beberapa ketentuan yang dipersyaratkan oleh pemerintah dalam penyaluran KUR adalah sebagai berikut (Suplemen 4, Serba-Serbi Kredit Usaha Rakyat, Bank Indonesia) :

a. UMKM-K yang dapat menerima fasilitas penjaminan adalah usaha produktif yangfeasible namun belum bankable dengan ketentuan :

1. Merupakan debitur baru yang belum pernah mendapat kredit/ pembiayaan dari perbankan yang dibuktikan dengan melalui Sistem Informasi Debitur (SID) pada saat Permohonan Kredit/Pembiayaan diajukan dan/ atau belum pernah memperoleh fasilitas Kredit Program dari Pemerintah

2. Khusus untuk penutupan pembiayaan KUR antara tanggal Nota Kesepakatan Bersama (MoU) Penjaminan KUR dan sebelum addendum I (tanggal 9 Oktober 2007 s.d. 14 Mei 2008), maka fasilitas penjaminan dapat diberikan kepada debitur yang belum pernah mendapatkan pembiayaan kredit program lainnya 
3. KUR yang diperjanjikan antara Bank Pelaksana dengan UMKM-K yang bersangkutan.

b. KUR disalurkan kepada UMKM-K untuk modal kerja dan investasi dengan ketentuan:

1. Untuk kredit sampai dengan Rp. 5 juta, tingkat bunga kredit atau margin pembiayaan yang dikenakan maksimal sebesar atau setara $20-21 \%$ efektif pertahun

2. Untuk kredit di atas Rp. 5 juta rupiah sampai dengan Rp. 500 juta, tingkat bunga kredit atau margin pembiayaan yang dikenakan maksimal sebesar atau setara $12-13 \%$ efektif pertahun.

c. Bank pelaksana memutuskan pemberian Kredit Usaha Rakyat (KUR) berdasarkan penilaian terhadap kelayakan usaha sesuai dengan asas-asas perkreditan yang sehat, serta dengan memperhatikan ketentuan yang berlaku.

\subsection{Tinjauan Usaha Kecil dan Menengah}

\subsubsection{Defenisi dan Karakteristik Usaha Mikro Kecil dan Menengah}

Berdasarkan Undang-Undang Nomor 20 Tahun 2008 tentang Usaha Mikro, Kecil dan Menengah (UMKM) ada beberapa kriteria yang dipergunakan untuk mendefinisikan Pengertian dan kriteria
Usaha Mikro, Kecil dan Menengah. Pengertian-pengertian UMKM tersebut adalah :

1. Usaha Mikro

Kriteria kelompok Usaha Mikro adalah usaha produktif milik orang perorangan dan/atau badan usaha perorangan yang memenuhi kriteria Usaha Mikro sebagaimana diatur dalam Undang-Undang ini.

2. Usaha Kecil

Kriteria Usaha Kecil Adalah usaha ekonomi produktif yang berdiri sendiri, yang dilakukan oleh orang perorangan atau badan usaha yang bukan merupakan anak perusahaan atau bukan cabang perusahaan yang dimiliki, dikuasai, atau menjadi bagian baik langsung maupun tidak langsung dari usaha menengah atau usaha besar yang memenuhi kriteria Usaha Kecil sebagaimana dimaksud dalam Undang-Undang ini.

3. Usaha Menengah

Kriteria Usaha Menengah Adalah usaha ekonomi produktif yang berdiri sendiri, yang dilakukan oleh orang perseorangan atau badan usaha yang bukan merupakan anak perusahaan atau cabang perusahaan yang dimiliki, dikuasai, atau menjadi bagian baik 
langsung maupun tidak langsung dengan usaha kecil atau usaha besar dengan jumlah kekayaan bersih atau hasil penjualan tahunan sebagaimana diatur dalam UndangUndang ini.

\subsubsection{Masalah yang dihadapi Industri} Kecil dan Menengah (IKM)

Menurut Hubeis (2009: 4-6) permasalan umum yang biasanya terjadi pada IKMyaitu :

a. Kesulitan pemasaran Pemasaran sering dianggap sebagai salah satu kendala yang kritis bagi perkembangan IKM. Dari hasil studi yang dilakukan oleh james dan akrasanee (1988) di sejumlah negara ASEAN, menyimpulkan IKM tidak melakukan perbaikan yang cukup di semua aspek yang terkait dengan pemasaran seperti peningkatan kualitas produk dan kegiatan promosi, sulit sekali bagi IKM untuk dapat turut berpartisipasi dalam era perdagangan bebas.

b. Keterbatasan Finansial

Terdapat dua masalah utama dalam kegiatan IKM di Indonesia, yakni dalam aspek finansial (mobilisasi modal awal dan akses ke modal kerja) dan finansial jangka panjang untuk investasi yang sangat diperlukan demi pertumbuhan output jangka panjang. Walaupun pada umumnya modal awal bersumber dari modal (tabungan) sendiri atau sumbersumber informal, namu sumbersumber permodalan ini sering tidak memadai dalam bentuk kegiatan produksi maupun investasi. Walaupun begitu banyak skim-skim kredit dari perbankan dan bantuan Badan Usaha Milik Negara (BUMN), sumber pendanaan dari sektor informal masih tetap dominan dalam pembiayaan kegiatan IKM.

\section{c. Keterbatasan SDM}

Salah satu kendala serius bagi banyak IKM di Indonesia adalah keterbatasan SDM terutama dalam aspek-aspek entrepreneurship, manajemen, teknik produksi, pengembangan produk, engineering design, quality control, organisasi bisnis, akuntansi data processing, teknik pemasaran, dan penelitian pasar. Semua keahlian ini sangat dibutuhkan untuk mempertahankan atau memperbaiki kualitas produk, meningkatkan efisiensi dan produktivitas dalam produksi, memperluas pangsa pasar dan menembus pasar barang. 
d. Masalah Bahan Baku

Keterbatasanbahan baku serta kesulitan dalam memeperolehnya dapat menjadi salah satu kendala yang serius bagi banyak IKM di Indonesia. Hal ini dapat disebabkan harga yang relatif mahal. Banyak pengusaha yang terpaksa berhenti dari usaha dan berpindah profesi ke kegiatan ekonomi lainnya akibat masalah keterbatasan bahan baku.

e. Keterbatasan Teknologi

IKM di Indonesia umumnya masih menggunakan teknologi yang tradisional, seperti mesin-mesin tua atau alat-alat produksi yang bersifat manual. Hal ini membuat produksi menjadi rendah, efisiensi menjadi kurang maksimal, dan kualitas produk relatif rendah.

f. Kemampuan Manajemen

Kekurangmampuan pengusaha kecil untuk menentukan pola manajemen yang sesuai dengan kebutuhan dan tahap pengembangan usahanya, membuat pengelolaan usaha menjadi terbatas.

g. Kemitraan

Kemitraan mengacu pada pengertian berkerja sama antara pengusaha dengan tingkatan yang berbeda yaitu antara pengusaha kecil dan pengusaha besar. Istilah kemitraan sendiri mengandung arti walaupun tingkatannya berbeda, hubungan yang terjadi adalah hubungan yang setara (sebagai mitra kerja).

\subsection{Kerangka Pemikiran}

Secara sederhana kerangka konseptual di dalam penelitian ini dapat dilihat dalam gambar 1.berikut ini :

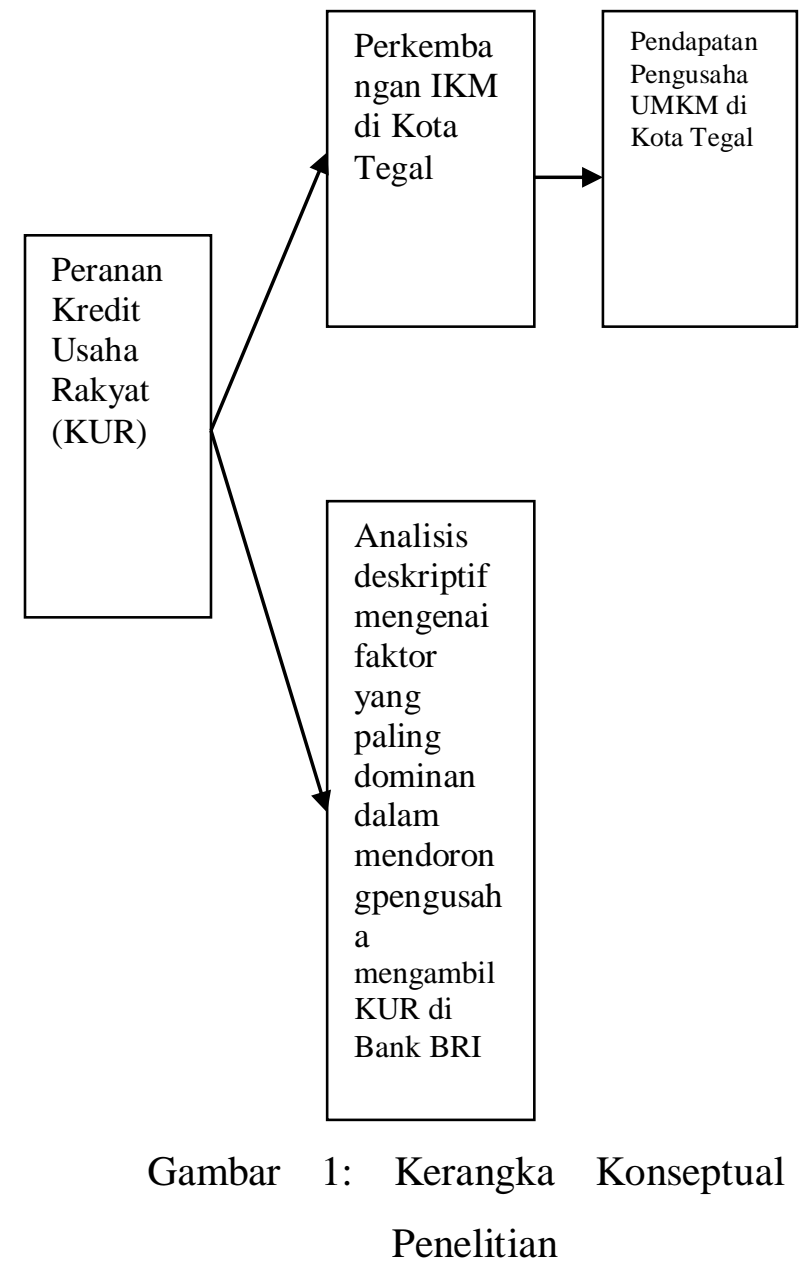


Bagian ini berisikan literatur-literatur atau penelitian sebelumnya yang terkait dengan penelitian ini dan selanjutnya dilakukan pengembangan hipotesis berdasarkan literatur dan penelitian terdahulu yang telah dilakukan.

\subsection{Hipotesis}

Program KUR bertujuan untuk meningkatkan perekonomian khususnya di bidang usaha mikro, kecil dan menengah, pengentasan kemiskinan dan penyerapan tenaga kerja.Kesulitan pemasaran Pemasaran sering dianggap sebagai salah satu kendala yang kritis bagi perkembangan IKM.

H1 : Kredit Usaha Rakyat berpengaruh terhadap perkembangan Industri Kecil Menengah.

\section{METODE PENELITIAN}

\subsection{Populasi dan Sampel}

Populasi dalam penelitian ini adalah seluruh pelaku Industri Kecil dan Menengah di Kota Tegal yang menggunakan Kredit Usaha Rakyat (KUR). Sampel dalam penelitian ini adalah berjumlah 49 responden dengan menggunakan accidental sampling.

\subsection{Instrumen Penelitian}

Instrumen penelitian dalam penelitian ini adalah Angket / Kuisioner. Semua data diklasifikasikan ke dalam indikator-indikator yang dikonstruksikan dalam instrumen kuisioner. Daftar pertanyaan yang akan disampaikan kepada responden yang dijawab adalah daftar pertanyaan yang sudah disusun. Daftar pertanyaan terbagi dua yaitu mengenai implementasi dalam bentuk pertanyaan terbuka. Dari jawaban responden kemudian dilakukan analisis secara kualitatif.

\subsection{Metode analisis data}

Metode analisis data yang digunakan dalam penelitian ini adalah :

1. Verifikasi data, yaitu memeriksa kembali kuisioner yang telah diisi responden untuk mengetahui apa-kah sudah dijawab lengkap oleh responden atau belum dengan tujuan menghindari terjadinya missing value.

2. Analisis kuantitatif. Untuk memperoleh kesimpulan terhadap ma-salah yang dikemukakan, maka data yang diperoleh akan Dianalisis dengan menggunakan Regresi Linier Berganda. Metode analisis regresi linear berganda berfungsi untuk mengetahui pengaruh/hubungan variabel bebas dan variabel terikat. Pengolahan data akan dilakukan dengan 
menggunakan alat bantu aplikasi Software SPSS 20.00 for Windows.

\section{HASIL PENELITIAN DAN PEMBAHASAN}

\subsection{Deskriptif Perkembangan KUR}

Deskriptif karakteristik berdasarkan jenis usaha dapat dibagi atas empat kategori, dimana usaha perdagangan sebanyak 29 orang $(59,18 \%)$. Selanjutnya petani sebanyak 9 orang $(18,36 \%)$. Untuk PNS sebanyak 11 orang (22,44\%). Dan untuk TNI / Polritidak ada (0\%). Gambaran keadaan tersebut menggambarkan bahwa usaha perdagangan merupakan usaha yang paling banyak dibiayai oleh Kredit Usaha Rakyat (KUR). Deskriptif karakteristik berdasarkan lama usaha dibagi atas enam kategori, dimana persentase terbanyak adalah kisaran 3-4 tahun sebanyak 15 orang $(30.61 \%)$. Selanjutnya diikuti oleh $>10$ tahun sebanyak 12 orang $(24,49 \%)$. Untuk kisaran 5-6 tahun sebanyak 8 orang (16,33\%). Untuk kisaran 910 tahun sebanyak 7 orang (14,29\%). Untuk kisaran 1-2 tahun sebanyak 5 orang $(10,20 \%)$. Sedangkan persentase terkecil berada pada kisaran 7-8 tahun sebanyak 1 orang $(4,8 \%)$. Gambaran keadaan tersebut menjelaskan bahwa kisaran lama usaha 3-4 tahun membutuhkan modal untuk mengembangkan usahanya. Deskriptif karakteristik berdasarkan tingkat pendapatan dibagi atas lima kategori, dimana persentase terbanyak adalah kisaran Rp 3.000.000 - Rp 4.000.000 sebanyak 17 orang $(34,69 \%)$ dan Rp 1.000.000 - Rp 2.000.000 masing-masing sebanyak 14 orang (28,57\%). Selanjutnyakisaran $\mathrm{Rp} 7.000 .000-\mathrm{Rp}$ 8.000.000 sebanyak 8 Orang (16,33\%). Untuk kisaran Rp 9.000.000-10.000.000 sebanyak 6 orang (12,24\%). Sedangkan persentase terkecil berada pada kisaran $\mathrm{Rp}$ 5.000.000-Rp 6.000.000 sebanyak 4 orang $(8,16 \%)$.

\subsection{Hasil Persamaan Regresi}

Berdasarkan hasil pengujian dengan metode regresi linier berganda untuk menguji pengaruh variabelvariabel independen (modal sendiri dan modal KUR) terhadap variabel dependen (pendapatan) maka dapat disusun sebuah persamaan sebagai berikut :

$Y=7664,575+120,896 \mathbf{X 1}+0,396 \mathbf{X} 2$ $+\mathbf{e}$

Berdasarkan persamaan di atas dapat dijelaskan sebagai berikut :

1. Nilai konstanta regresi adalah sebesar 7664,575 dengan tanda positif yang berarti jika semua variabel independen (modal sendiri dan modal KUR) diasumsikan 
konstan maka variabel pendapatan akan naik sebesar 7664,575.

2. Nilai koefisien regresi variabel modal sendiri adalah sebesar 120,896 yang berarti bahwa setiap peningkatan modal sendiri sebesar 1 satuan maka akan meningkatkan pendapatan sebesar 120,896.

3. Nilai koefisien regresi variabel modal setelah KUR adalah sebesar 0,396 yang berarti bahwa setiap peningkatan modal sendiri sebesar 1 satuan maka akan meningkatkan pendapatan sebesar 0,396 .

Hasil pengujian menunjukkan sebagai berikut :

a. Variabel modal sendiri memiliki nilai t sebesar 10,757 dengan tingkat signifikansi 0,000 lebih kecil dari taraf signifikansi 0,05 (5\%). Hal ini menunjukkan bahwa modal sendiri terbukti berpengaruh secara positif dan signifikan terhadap pendapatan IKM

b. Variabel modal setelah KUR memiliki nilai t sebesar 3,958 dengan tingkat signifikansi 0,000 lebih kecil dari taraf signifikansi 0,05 (5\%). Hal ini menunjukkan bahwa modal setelah KUR terbukti berpengaruh secara positif dan signifikan terhadap pendapatan IKM.

\section{SIMPULAN}

Melalui hasil pembahasan terhadap peran kredit usaha rakyat bagi pengembangan IKM di kota Tegal maka dapat disimpulkan sebagai berikut:

1. Konstanta

(a)

sebesar

7664,575 mempunyai arti bahwa variabel modal sendiri dan variabel modal kredit usaha rakyat (KUR) dianggap konstan maka tingkat pendapatan sebesar 7664,575.

2. Koefisien regresi realisasi kredit sebesar 0.396 adalah besarnya pengaruh variabel bebas x1 (modal sendiri) terhadap perubahan tingkat pendapatan pengusaha IKM, pengaruh ini bernilai positif atau dapat dikatakan semakin besar modal sendiri yang diberikan maka menyebabkan semakin tinggi pula tingkat pendapatan yang akan

\begin{tabular}{|l|r|r|r|r|r|}
\hline \multirow{2}{*}{ Model } & \multicolumn{2}{|c|}{$\begin{array}{c}\text { Unstandardized } \\
\text { Coefficients }\end{array}$} & $\begin{array}{r}\text { Standardized } \\
\text { Coefficients }\end{array}$ & & \\
\cline { 2 - 4 } & B & Std. Error & Beta & T & Sig. \\
\hline (Constant) & $\mathbf{7 6 6 4 , 5 7 5}$ & 699,506 & & & \\
Modal Sendiri & $\mathbf{1 2 0 , 8 9 6}$ & 11,239 &, 762 & $\mathbf{1 0 , 7 5 7}$ & $\mathbf{, 0 0 0}$ \\
Modal KUR & $\mathbf{3 1 8 , 3 8 2}$ & 80,435 &, 280 & $\mathbf{3 , 9 5 8}$ & $\mathbf{, 0 0 0}$ \\
\hline
\end{tabular}


didapatkan oleh pengusaha IKM, demikian pula sebaliknya.

3. Koeefisien regresi modal KUR sebesar 3,958 adalah besarnya pengaruh variabel bebas x2 (modal kredit usaha) terhadap perubahan tingkat pendapatan pengusaha IKM, pengraruh ini bernilai positif atau dapat dikatakan semakin besar jumlah modal kredit usaha rakyat maka semakin tinggi pula tingkat pendapatan yang akan didapatkan pengusaha IKM, demikian pula sebaliknya.

\section{SARAN}

1. Untuk dapat meningkatkan program bantuan kredit usaha rakyat sebaiknya pemerintah melalui bank-bank yang telah ditunjuk pemerintah tetap menjalankan program tersebut. Akan tetapi, dilakukan pendataan ulang untuk IKM yang akan menerima ataupun yang sudah menerima kredit usaha rakyat agar tidak terjadi penyalahgnaan manfaat dan tujuan diberikannya kredit usaha rakyat.

2. Untuk para pengusaha IKM, bahwa dalam penggunaan kredit usaha utnuk tidak mencampur adukan dengan kebutuhan konsumsi agar pemanfaatannya lebih bijak dan lebih efisien sehingga hasil pun akah terlihat maksimal.

3. Bagi pihak PT Bank Rakyat Indonesia selaku bank milik pemerintah disamping menawarkan produk pinjaman modal syarat dengan profit motive agar juga melakukan penyuluhan dan pengarahan kepada para pengusaha IKM. Sehingga wujud tanggung jawab pemerintah untuk mensejahterakan rakyat dapat terlaksana.

\section{DAFTAR PUSTAKA}

Sastradipoera, komarudin, 2004. Strategi manajemen BIsnis Perbankan: Konsep dan Implementasi untuk Bersaing, Penerbit Kappa Sigma, Bandung

Kartajaya, H.2004. On Brand. Bandung: Mizan Media Utama

K.L Keller. 2006. Manajemen Pemasran. Kualitas Jasa. Edisi Kedua, terjemahan Ancella Anitawati, Penerbit PT. Prenhalindo Jakarta.

Kotler, Philip dan G Armstrong. 2006. Principles of Marketing. $11^{\text {th }}$ Edition, Prentice Hall International Inc. New Jersey 
Jurnal MONEX Volume 8 Nomor. 1 Januari 2019

p-ISSN: 2089-6778

e-ISSN: 2549-5054

Simamora, Bilson. 2004. Analisis Multivariat

Pemasaran. Jakarta: PT Gramedia Pustaka Utama

Silva, Rui Vnhas Da and Alwi, Sharifah FAridah Syad.2008.”Online Corporate Brand Image, Satisfaction and Loyalty" Brand Management.Vol 16. No.3 pp 119-144

Tjiptono, Fandy 1997. Strategi Pemasaran. Andi Offset Yogyakarta. 